\title{
EDUKASI KESADARAN SISWA TERHADAP PENCEGAHAN PENYEBARAN VARIAN OMICRON DALAM PEMBELAJARAN TATAP MUKA TERBATAS
}

\author{
Evi Susilawati ${ }^{1}$, Imamul Khaira ${ }^{2}$, Wiwik Afrida $^{3}$ \\ ${ }^{1}$ Universitas Islam Sumatera Utara, Medan, Indonesia \\ ${ }^{2}$,Universitas Haji Suamtera Utara, Medan, Indonesia \\ ${ }^{3}$ Perwakilan BKKBN Provinsi Sumatera Utara \\ Email: ${ }^{1}$ evisusilawati@fkip.uisu.ac.id, ${ }^{2}$ imamulkhaira@gmail.com, ${ }^{3}$ wiwik.pisces@gmail.com
}

\begin{abstract}
ABSTRAK
Program Pengabdian kepada Masyarakat ini bertujuan untuk mengedukasi pencegahan dan penanggulangan penyebaran Varian Omicron di masa Pandemi COVID-19 pada siswa Sekolah Dasar melalui media edukasi daring berupa gambar tentang pencegahan Varian Omicron di masa Pandemi COVID-19. Varian Omicron ini merupakan Varian baru dari Varian COVID-19 yang menunjukkan bahwa Omicron menimbulkan risiko infeksi ulang yang lebih tinggi. WHO menyebut varian baru ini telah mengalami sangat banyak mutasi, dibandingkan varian-varian lainnya. Untuk mengatasi penyebaran Varian tersebut dalam pelaksanaan Pembelajaran Tatap Muka Terbatas saat ini, perlu dilakukan pencegahannya dengan mengedukasi siswa Sekolah Dasar melalui kegiatan penggunaan media pembelajaran cetak dengan menggunakan poster. Tujuan kegiatan pengabdian kepada masyarakat ini agar para siswa dapat dengan mudah memahami bahaya penyebaran Varian Omicron salah satu Varian dari Covid-19 dan mampu melakukan pencegahannya secara tepat dengan menggunakan media cetak ini. Penggunaan media cetak dalam kegiatan edukasi ini dimaksudkan agar siswa dapat dengan mudah menerima informasi yang disampaikan oleh tim Pengabdian kepada Masyarakat. Efektifitas kegiatan Pengabdian kepada Masyarakat ini menggunakan kuesioner melalui kegiatan pre tes dan pos tes. Hasil dari pretes dan postes menunjukkan telah terjadi peningkatan kesadaran siswa dalam pencegahan dan penyebaran Varian Omicron dalam kegiatan Pembelajaran Tatap Muka Terbatas pada siswa Sekolah Dasar Setia Budi Abadi Kecamatan Perbaungan Kabupoaten Deli Serdang, Provinsi sumatera Utara pada tahun pelajaran 2021/2022.
\end{abstract}

Kata Kunci: Virus Omicron, Pembelajaran Tatap Muka Terbatas

\section{Pendahuluan}

Perubahan telah banyak terjadi ketika Pandemi Covid-19 mewabah. Khusus dalam kegiatan pembelajaran, telah banyak perubahan dalam proses pembelajaran bahkan juga perubahan dalam kurikulumnya. Pembelajaran tatap muka di ruang kelas konvensioanl di mana guru dapat bertemu secara tatap muka di suatu tempat dan ruang yang sama digantikan adengan kegiatan pembelajaran secara online. Banyak keutungan menggunakan pembelajaran online ini. Penggunaan pembelajaran online ini memberikan manfaat seperti: fleksibel dalam penggunaan waktu dan tempat sehingga mereka dapat meningkatkan efektivitas pengetahuan dan kualifikasi materi pelajaran melalui berbagai akses informasi 
secara cepat dan mudah (Susilawati \& Khaira, 2021). Selain kebermanfaatan pembelajaran online, tentunya ditemukan berbagai kelemahan dalam kegiatan pembelajaran online di masa Pandemi Covid 19 ini. Adapun kelemahan dari pembelajaran online adalah dalam hal bersosialisasi dan berkomunikasi melalui pembelajaran tatap muka secara konvensional menjadi hilang dan semua mahasiswa hanya berkomunikasi dengan teman-temanya melalui kegiatan online yang akhirnya di antara mereka tidak pernah melihat teman-temanya secara langsung, untuk berbagi ide-ide, pengetahuan, dan informasi secara nyata (Susilawati \& Khaira, 2020).

Seiring dengan berjalannya waktu, saat ini sudah dilaksanakan pemberian vaksin baik bagi guru maupun siswa, sehingga Pemerintah telah mengeluarkan peraturan tentang Pembelajaran Tatap Muka Terbatas pada tahun ajaran 2021/2022. Kebijakan yang dituangkan dalam Surat Keputusan Bersama (SKB) empat menteri yaitu Menteri Pendidikan dan Kebudayaan, Menteri Agama, Menteri Kesehatan, dan Menteri Dalam Negeri dengan memberi pilihan bagi sekolah untuk melaksanakan Pembelajaran Tatap Muka Terbatas dengan sayarat melaksanakan protokol kesehatan yang ketat. Kondisi ini tentunya meresahkan para orang tua dan pihak sekolah tentang rentannya para siswa tertular Covid-19 khususnya Varian Omicron. Banyak para orang tua siswa yang tidak mengizinkan anak-anak mereka melakukan Pembelajaran Tatap Muka Terbatas. Sebagaimana diketahui bahwa Varian Omicron ini yang dikenal sebagai varian B.1.1.529. Amalia (2021) menyatakan bahwa Varian Omicron memiliki kecepatan penularan yang tinggi bahkan sampai lima kali lipat dari varian sebelumnya termasuk varian Delta. Meskipun penyebarannya sangat tinggi, Tindakan vaksinasi dan menerapkan protokol kesehatan secara ketat menjadi kunci utama dalam mencegah penularan varian baru Covid-19 ini (Gusti, 2021).

Mencermati permasalahan tersebut, tim Pengabdian kepada Masyarakat Fakultas Keguruan dan Ilmu Pendidikan Universitas Islam Sumatera Utara dan Fakultas Sosial Humaniora Universitas Haji Sumatera Utara melakukan Pengabdian kepada Masyarakat melakukan edukasi kesadaran siswa terhadap pencegarah penyebaran Varians Omicron dalam Pembelajaran Tatap Muka Terbatas di Sekolah Dasar Setia Budi Abadi Kecamatan Perbaungan Kabupaten Serdang Bedagai, Provinsi Sumatera Utara pada tahun ajaran 2021/2022. Kegiatan Pengabdian kepada Masyarakat ini bertujuan: (1) memberikan peningkatan kesadaran kepada siswa Sekolah Dasar Setia Budi Abadi Kecamatan Perbaungan, Kabupaten Serdang Bedagai, Provinsi Sumatera Utara terhadap pencegahan penyebaran Varian Omicron dalam Pembelajaran Tatap Muka Terbatas, (2) memberikan dan memotivasi siswa tentang kesiapan siswa menlaksanakan Pembelajaran Tatap Muka Terbatas delngan melaksanakan Protokol kesehatan yang ketat sehingga 
terbebas dari Covid-19 terutama Varians Omicron. Kemudian kegiatan Pengabdian kepada Masyarakat ini telah memberikan manfaat pada: (1) peningkatan kesadaran siswa terhadap pencegahan penyebaran Varian Omicron dalam Pembelajaran Tatap Muka Terbatas di Sekolah Dasar Setia Budi Abadi Kecamatan Perbaungan, Kabupaten Serdang Bedagai, Provinsi Sumatera Utara, (2) peningkatan kesiapan siswa menlaksanakan Pembelajaran Tatap Muka Terbatas delngan melaksanakan Protokol kesehatan yang ketat sehingga terbebas dari Covid-19 terutama Varians Omicron.

\section{Metode}

Kegiatan edukasi kesadaran siswa terhadap pencegahan penyebaran Varian Omicron dalam Pembelajaran Tatap Muka Terbatas ini dilakukan di Sekolah Dasar Setia Budi Abadi yang beralamat di Simpang Tiga Pekan, Keamatan Perbaungan, Kabupaten Serdang Bedagai, Provinsi Sumatera Utara. Materi Pengabdian kepada Masyarakat yang tentang pencegahan penyebaran Varian Omicron seperti: (1) pemilihan masker yang baik, pengetahuan dalam menjaga kesehatan selama masa pandemi, (2) pengetahuan pembatasan fisik dan pembatasan sosial, (3) pengetahuan dan penerapan etika batuk dan bersin, (4) pengetahuan dan penerapan hand hygiene (cuci tangan) yang baik, (5) memakan makanan yang bergizi untuk pencegaran Varian Omicron. Subjek PkM terdiri dari siswa kelas 4 sampai siswa kelas 6 berjumlah 172 siswa. Kegiatan pengabdian dilakukan pada tanggal 17 Desember 2021 dengan memberikan pre test dan pos tes terhadap materi yang diberikan oleh narasumber. Kegiatan Pengabdian kepada Masyarakat ini dilakukan dengan tahapan-tahapan seperti yang di tampilkan pada Gambar 1:

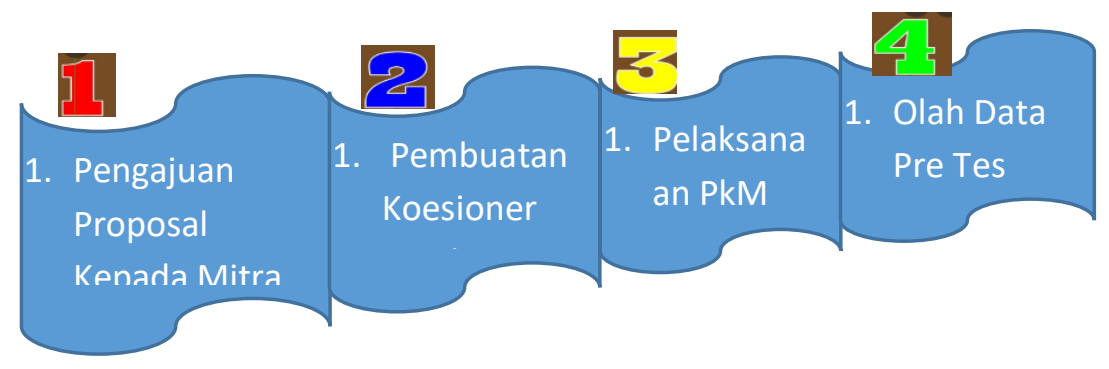

Gambar 1. Langkah-Langkah Kegiatan Pengabdian kepada Masyarakat Edukasi Kesadaran Siswa Terhadap Pencegahan Penyebaran Varian Omicron Dalam Pembelajaran Tatap Muka Terbatas di Sekolah Dasar Setia Budi Abadi Kecamatan Perbaungan, Kabupaten Serdang Bedagai, Provinsi Sumatera Utara 


\section{Hasil dan Pembahasan}

Kegiatan Pengabdian kepada Masyarakat edukasi kesadaran siswa terhadap pencegahan penyebaran Varian Omicron dalam Pembelajaran Tatap Muka Terbatas di Sekolah Dasar Setia Budi Abadi Kecamatan Perbaungan, Kabupaten Serdang Bedagai, Provinsi Sumatera Utara ini pada awal kegiatan dilakukan pengukuran tingkat pengetahuan yang berkaitan dengan materi PkM. Para peserta diberikan soal-soal pre tes yang berupa materi- materi tentang pencegahan penyebaran Varian Omicron seperti: (1) pemilihan masker yang baik, pengetahuan dalam menjaga kesehatan selama masa pandemi, (2) pengetahuan pembatasan fisik dan pembatasan sosial, (3) pengetahuan dan penerapan etika batuk dan bersin, (4) pengetahuan dan penerapan hand hygiene (cuci tangan) yang baik, (5) memakan makanan yang bergizi untuk pencegaran Varian Omicron. Soal-soal yang diberikan berupa soal-soal yang berbentuk multiple choice di mana peserta memilih salah satu jawaban yang benar dari beberapa jawaban yang tersedia. Untuk soal yang memiliki jawaban benar diberikan skore 100 sedangkan soal jawaban salah diberi skor 0 .Pengetahuan subjek PkM dikatakan tinggi apabila nilai yang didapat $\geq 80$ dan dikatakan rendah apabila nilai yang didapat di bawah 50 .

Setelah pemberian edukasi dan praktik tentang; (1) pemilihan masker yang baik, pengetahuan dalam menjaga kesehatan selama masa pandemi, (2) pengetahuan pembatasan fisik dan pembatasan sosial, (3) pengetahuan dan penerapan etika batuk dan bersin, (4) pengetahuan dan penerapan hand hygiene (cuci tangan) yang baik, (5) memakan makanan yang bergizi untuk pencegaran Varian Omicron dengan menggunakan poster, selanjutnya diberikan pos tes untuk mengukur kembali tingkat penegetahuan peserta materi edukasi. Soal yang diberikan kepada peserta untuk pos tes sama dengan soal pre-tes. Kegiatan Pos-tes dilakukan untuk mengetahui tingkat efektifitas PkM yang telah diberikan. Tingkat pengetahuan subjek dikelompokkan menjadi dua, yakni berpengetahuan tinggi dan berpengetahuan rendah berdasarkan nilai yang didapat dari hasil pos tes. Subjek dikatakan memiliki pengetahuan tinggi apabila skor pos tes $\geq 80$ dan dikatakan berpengetahuan rendah apabila skor pos tes 50. Pengukuran tingkat pengetahuan dilakukan dengan metode uji pre tes. Hasil pre tes peserta menunjukan bahwa kesadaran siswa terhadap pencegahan 
penyebaran Varian Omicron dalam Pembelajaran Tatap Muka Terbatas sebesar 54\% dari soal-soal yang diberikan pada waktu pre tes. Selanjutnya Hasil pos tes peserta menunjukan bahwa telah terjadi peningkatan kesadaran siswa terhadap pencegahan penyebaran Varian Omicron dalam Pembelajaran Tatap Muka Terbatas sebesar 86\% dari soal-soal yang diberikan pada waktu pos tes. Hasil pre tes dan pos tes ini menjadi indikator keberhasilan program Pengabdian kepada Masyarakat di mana adanya peningkatan kesadaran siswa Sekolah Dasar Setia Budi Abadi Kecamatan Perbaungan, Kabupaten Serdang Bedagai, Provinsi Sumatera Utara terhadap pencegahan penyebaran Varian Omicron dalam Pembelajaran Tatap Muka Terbatas. Hasil pos tes ini menunjukkan tentang pentingnya kesadaran siswa terhadap pencegahan penyebaran Varian Omicron dalam Pembelajaran Tatap Muka Terbatas. Pada dasarnya, diperlukan kesadaran masyarakat terutama para siswa yang sedang bersekolah dengan menggunakan Pembelajaran Tatap Muka Terbatas dalam menjaga kesehatan di masa Pandemi Covid 19. Temuan Pengabdian kepada Masyarakat ini sejalan dengan pendapat Yatimah dkk (2020) yang menyatakan bahwa masyarakat terutama siswa dianjurkan untuk menjaga kesehatan misalnya dengan sering mencuci tangan, memakai masker di tempat umum, menghindari orang yang sedang pilek maupun batuk, menjaga jarak fisik, serta senantiasa menghindari tempat-tempat keramaian.

\section{Kesimpulan}

Kesimpulan yang dapat diambil dari uraian kegiatan Pengabdian kepada Masyarakat edukasi kesadaran siswa terhadap pencegahan penyebaran Varian Omicron dalam Pembelajaran Tatap Muka Terbatas di Sekolah Dasar Setia Budi Abadi Kecamatan Perbaungan, Kabupaten Serdang Bedagai, Provinsi Sumatera Utara sebagai berikut: Pertama adanya peningkatan kesadaran siswa Sekolah Dasar Setia Budi Abadi Kecamatan Perbaungan, Kabupaten Serdang Bedagai, Provinsi Sumatera Utara terhadap pencegahan penyebaran Varian Omicron dalam Pembelajaran Tatap Muka Terbatas. Kedua, telah terjadi peningkatan memotivasi siswa dan kesiapan siswa dalam melaksanakan Pembelajaran Tatap Muka Terbatas dengan melaksanakan Protokol kesehatan yang ketat sehingga terbebas dari Covid-19 terutama Varians Omicron. Hasil pre tes peserta menunjukan bahwa kesadaran siswa terhadap pencegahan penyebaran Varian Omicron dalam Pembelajaran Tatap Muka Terbatas sebesar 54\% dari soal-soal yang diberikan pada waktu pre tes. Selanjutnya berdasarkan hasil pos tes peserta telah telah terjadi peningkatan 
kesadaran siswa terhadap pencegahan penyebaran Varian Omicron dalam Pembelajaran Tatap Muka Terbatas sebesar $86 \%$ dari soal-soal yang diberikan. Hasil pre tes dan pos tes ini menunjukkan terjadi peningkatan kesadaran siswa Sekolah Dasar Setia Budi Abadi Kecamatan Perbaungan, Kabupaten Serdang Bedagai, Provinsi Sumatera Utara terhadap pencegahan penyebaran Varian Omicron dalam Pembelajaran Tatap Muka Terbatas.

\section{Referensi}

Amalia, Husnun,. (2021). Omicron Penyebab COVID-19 Sebagai Variant of Concern. Jurnal Biomedika dan Kesehatan. Volume 4. No 4. Desember 2021. Dikases dari https://jbiomedkes.org/index.php/jbk/

Gusti,. (2021). Pakar UGM: Omicron Belum Terbukti Lebih Menular dari Delta. Liputan Berita Utama UGM. Diakses dari: https://ugm.ac.id/id/berita/22026-pakar-ugmomicron-belum-terbukti-lebih-menular-dari-delta.

Susilawati, Evi., Khaira, Imamul., Web-Based Learning Implementation to Improve Students' Learning Outcomes on Understand Evaluating the Public Policies' Impact Material during the Covid-19 Pandemic. (2021). $1^{\text {st }}$ Education Research and Applied Business Conference. Volume 2021.

Susilawati, Evi., Khaira, Imamul., Upaya Meningkatkan Keaktifan Mahasiswa dalam Menganalisis Video Pembelajaran Melalui strategi Pembelajaran Webinar. (2020). Jurnal Teknologi Pendidikan. Vol. 13, No. 2, Oktober 2020. Diakses dari: https://jurnal.unimed.ac.id/2012/index.php/jtp/article/

Yatimah, Durotul, dkk,. (2020). Peningkatan Kesadaran Masyarakat tentang Pencegahan COVID-19 berbasis Keluarga dengan Memanfaatkan Motion Grafis di Jakarta Timur. Jurnal Karya Abdi. Volume 4. Nomor 1 Juni 2020. Diakses dari; https://online-journal.unja.ac.id > article. 